\title{
Leaf shape linked to photosynthetic rates and temperature optima in South African Pelargonium species
}

\author{
A. B. Nicotra $\cdot$ M. J. Cosgrove $\cdot$ A. Cowling $\cdot$ \\ C. D. Schlichting $\cdot$ C. S. Jones
}

Received: 23 August 2006/ Accepted: 12 September 2007/Published online: 18 October 2007

(C) Springer-Verlag 2007

\begin{abstract}
The thermal response of gas exchange varies among plant species and with growth conditions. Plants from hot dry climates generally reach maximal photosynthetic rates at higher temperatures than species from temperate climates. Likewise, species in these environments are predicted to have small leaves with more-dissected shapes. We compared eight species of Pelargonium (Geraniaceae) selected as phylogenetically independent contrasts on leaf shape to determine whether: (1) the species showed plasticity in thermal response of gas exchange when grown under different water and temperature regimes, (2) there were differences among more- and less-dissected leafed species in trait means or plasticity, and (3) whether climatic variables were correlated with the responses. We found that a higher growth temperature led to higher optimal photosynthetic temperatures, at a cost to photosynthetic capacity. Optimal temperatures for photosynthesis were greater than the highest growth temperature regime. Stomatal conductance responded to growth water regime but not growth temperature, whereas transpiration increased and water use efficiency (WUE) decreased at the higher growth temperature. Strikingly, species with more-dissected leaves had
\end{abstract}

Communicated by Kouki Hikosaka.

A. B. Nicotra $(\bowtie) \cdot$ M. J. Cosgrove

School of Botany and Zoology, The Australian National

University, Canberra ACT 0200, Australia

e-mail: Adrienne.Nicotra@anu.edu.au

\section{A. Cowling}

Statistical Consulting Unit, The Australian National University,

Canberra ACT 0200, Australia

C. D. Schlichting · C. S. Jones

Department of Ecology and Evolutionary Biology,

University of Connecticut, Storrs, CT 06269, USA higher rates of carbon gain and water loss for a given growth condition than those with less-dissected leaves. Species from lower latitudes and lower rainfall tended to have higher photosynthetic maxima and conductance, but leaf dissection did not correlate with climatic variables. Our results suggest that the combination of dissected leaves, higher photosynthetic rates, and relatively low WUE may have evolved as a strategy to optimize water delivery and carbon gain during short-lived periods of high soil moisture. Higher thermal optima, in conjunction with leaf dissection, may reflect selection pressure to protect photosynthetic machinery against excessive leaf temperatures when stomata close in response to water stress.

Keywords Dissection index - Evaporative cooling . Temperature response Photosynthesis .

Stomatal conductance

\section{Introduction}

The process of photosynthesis is broadly dependent on temperature and water availability. When temperatures for photosynthesis are optimal, however, water availability is often low. Thermal optima for photosynthesis vary among species, with $\mathrm{C}_{3}$ plants generally having optima (i.e., able to maintain $90 \%$ of maximum rates) at temperatures between 20 and $30^{\circ} \mathrm{C}$ (Larcher 1995), whereas arid and desert plants, and $\mathrm{C}_{4}$ and CAM plants have higher optima (30-40 ${ }^{\circ} \mathrm{C}$, Larcher 1995$)$ as well as broader optimal ranges (Berry and Björkman 1980; Downton et al. 1984).

The shape of the temperature response curve is determined by different factors at low, moderate and high temperatures (Hikosaka et al. 1999; Xiong et al. 1999; Haldimann and Feller 2005; Sharkey 2005; Yamori et al. 
2005; Hikosaka et al. 2006), with critical points varying depending on growth temperatures (Berry and Björkman 1980), plant water status and even time of day (Lange et al. 1977; Valladares and Pearcy 1997; Medlyn et al. 2002). Within species, thermal optima have been shown to be higher in plants grown at higher temperatures, and a growing body of evidence suggests that critical temperatures for thermal tolerance are often plastic within species (Froux et al. 2004). Recent comparative studies show plasticity, but few consistent differences among species from different environments in thermal tolerance of photosynthesis (Knight and Ackerly 2002; 2003; but see Atkin et al. 2006).

Critical temperatures for damage of photosystem II are usually above $45^{\circ} \mathrm{C}$ (Sharkey 2005). So under most growing conditions, neither air temperatures nor average leaf temperature will exceed critical temperatures. However, under conditions of water stress, stomata may close before photosynthetically critical temperatures are reached; in the absence of evaporative cooling, the leaves of plants in sunny arid environments may then reach critical temperatures (Valladares and Pearcy 1997). Even though stomata may respond to temperature itself (Shabala 1996), and drought stress has been shown to increase thermotolerance in some species (Havaux 1992; Ladjal et al. 2000), very few species actively cool using the transpiration stream, even under ideal water conditions. Even where reduced leaf temperature has been associated with high stomatal conductance (Radin et al. 1994; Mahan and Upchurch 1988; Upchurch and Mahan 1988), there is limited evidence that stomatal opening is a direct response to high temperatures (but see Dwyer et al. 2007).

Leaf shape is considered to be another way that plants solve problems of high leaf temperatures: lobed or dissected leaves will have thinner boundary layers and therefore greater convective cooling (Nobel 1983; and see references in Schuepp 1993). However, evidence for an effect of leaf shape on leaf temperature in the field is inconclusive (Smith 1978; Hegazy and El Amry 1998), and while leaves are generally smaller in hot and dry climates, leaf dissection has not been shown reliably to be more common under these conditions (McDonald et al. 2003).

With rising global temperatures, there is increasing interest in identifying and evaluating plant traits that determine both photosynthetic optima and thermal tolerance. In particular, it is important to establish to what extent these traits are plastic in response to changes in average growth temperatures and water availability. Relevant traits include photosynthetic rates, water use parameters and morphological features such as leaf shape.

In this study we compared eight South African species of Pelargonium (Geraniaceae) selected as phylogenetically independent contrasts (PICs) on leaf shape (Burt 1989).
Pelargonium is an ideal genus with which to address these questions because leaf shape is an evolutionarily labile trait, with more-dissected leaf forms evolving independently multiple times within the genus (Jones et al., in preparation). We asked whether: (1) the species showed plasticity in thermal response of gas exchange when grown under different water and temperature regimes, (2) there were differences among more- and less-dissected leafed species in these traits or their plasticities, and (3) attributes such as latitude or rainfall at the sites of seed origin were correlated with the responses.

\section{Materials and methods}

\section{Study species}

Eight species of Pelargonium were selected as four PICs contrasted on leaf shape using images (van der Walt 1977; van der Walt and Vorster 1981, 1988) and a molecular phylogeny (Bakker et al. 2004 and references therein). Within a section of the genus, species were selected to maximize difference in leaf shape, dependent on availability of seed. Species were paired for growth form and geographic region as possible. Seeds from single populations were collected in the field by Rachel Saunders from Silverhill Seeds (Cape Town, South Africa; Table 1), with the exception of seeds of Pelargonium klinghardtense, and Pelargonium oblongatum, which were obtained ex hort or from specimens in cultivation at the University of Connecticut Greenhouse.

Propagation and experimental design

In late February and early March 2003, seeds were sown in seedling plugs in fine, washed river sand and kept in a glasshouse at $20 / 10^{\circ} \mathrm{C}$ (day/night). In early May, seedling plugs were potted into $150-\mathrm{mm}$ standard plastic pots in a custom soil mix of 1:1 decomposed pine bark fines and coarse washed river sand. The mix was pasteurised at $60^{\circ} \mathrm{C}$ for $3 \mathrm{~h}$, a medium dose of micronutrients was added (Micromax, $0.5 \mathrm{~kg} \mathrm{~m}^{-3}$ ), and the soil was then processed in a commercial mixer.

Plants were given 2 weeks to adjust to transplanting, and then experimental treatments were introduced. Plants were randomly allocated to one of two greenhouse compartments under either cool $\left(18 / 8^{\circ} \mathrm{C}\right.$ day/night $)$ or hot $\left(28 / 18^{\circ} \mathrm{C}\right.$ day/night) conditions. Temperatures were chosen to represent average early- and high late-season natural growing conditions, respectively. Each PIC pair was randomly assigned to a bench in the same position in the two glasshouses. To minimise concerns about pseudo- 
Table 1 Leaf shape (a typical leaf from the $18 / 8^{\circ} \mathrm{C}$, low-water treatment, at $25 \%$ actual size), section, number of replicates used in gas exchange, habitat characteristics and mean dissection index (perimeter/square root of area) of study species. Habitat characteristics based on collection site for all field-collected species

\begin{tabular}{|c|c|c|c|c|c|c|c|}
\hline Section & Species (no.) ${ }^{\mathrm{a}}$ & Habitat & $\begin{array}{l}\text { Daily } \\
\text { temperature: } \\
\text { July }\left({ }^{\circ} \mathrm{C}\right)\end{array}$ & $\begin{array}{l}\text { Average } \\
\text { rainfall } \\
(\mathrm{mm})\end{array}$ & $\begin{array}{l}\text { Rainy } \\
\text { season }\end{array}$ & $\begin{array}{l}\text { Growth } \\
\text { form }\end{array}$ & $\begin{array}{l}\text { Dissection } \\
\text { index }\end{array}$ \\
\hline \multirow[t]{2}{*}{ Reniformia } & $\begin{array}{l}\text { Pelargonium } \\
\text { reniforme (8) }\end{array}$ & $\begin{array}{l}\left(3317^{\prime} \mathrm{S}, 2631^{\prime} \mathrm{E}\right) \text { Karoid } \\
\text { shrubland, shale and } \\
\text { quartzitic sandstone, well } \\
\text { drained, } 600 \mathrm{~m}\end{array}$ & $4-18$ & 380 & All year & Sub-shrub & 4.7 \\
\hline & $\begin{array}{l}\text { Pelargonium } \\
\quad \text { ionidiflorum (6) }\end{array}$ & $\begin{array}{l}\left(3310^{\prime} \mathrm{S}, 2635^{\prime} \mathrm{E}\right) \text { Karoid } \\
\text { shrubland, well drained, } \\
\text { between rocks in karoo } \\
\text { or karroid vegetation, } \\
600-1,000 \mathrm{~m}\end{array}$ & $4-18$ & $300-760$ & All year & Sub-shrub & 8.1 \\
\hline \multirow[t]{2}{*}{ Pelargonium } & $\begin{array}{l}\text { Pelargonium } \\
\text { cucullatum }(8)\end{array}$ & $\begin{array}{l}\left.\text { (34 25'S, } 1910^{\prime} \mathrm{E}\right) \text { Fynbos, } \\
\text { Table Mountain derived } \\
\text { sandstone, chronically } \\
\text { nutrient poor, well } \\
\text { drained, } 2 \mathrm{~m}\end{array}$ & $8-17$ & $760-890$ & Winter & Shrub & 6.3 \\
\hline & $\begin{array}{l}\text { Pelargonium } \\
\quad \text { citronellum }(9)\end{array}$ & $\begin{array}{l}\left(3355^{\prime} \mathrm{S}, 2133^{\prime} \mathrm{E}\right) \text {, Little } \\
\text { karoo, alluvial Table } \\
\text { Mountain sandstone, well } \\
\text { drained, } 300 \mathrm{~m}\end{array}$ & $4-18$ & $200-300$ & Winter & Shrub & 14.5 \\
\hline \multirow[t]{2}{*}{ Hoarea } & $\begin{array}{l}\text { Pelargonium } \\
\text { oblongatum }^{\mathrm{b}} \\
\quad(20)\end{array}$ & $\begin{array}{l}\text { Richtersveld and Northern } \\
\text { Namaqualand, Garlep } \\
\text { Centre, succulent karoo, } \\
\text { gravelly areas, 500- } \\
1000 \mathrm{~m}\end{array}$ & $4-20$ & $50-180$ & winter & $\begin{array}{l}\text { Ephemeral } \\
\text { geophyte }\end{array}$ & 6.5 \\
\hline & $\begin{array}{l}\text { Pelargonium } \\
\quad \text { incrassatum } \\
\quad(10)\end{array}$ & $\begin{array}{l}\left.\text { (30 23'S, } 1754^{\prime} \mathrm{E}\right), \\
\text { Namaqualand broken } \\
\text { veld, decomposed } \\
\text { granite, well drained, } \\
800 \mathrm{~m}\end{array}$ & $6-20$ & $150-250$ & Winter & $\begin{array}{l}\text { Ephemeral } \\
\text { geophyte }\end{array}$ & 12.2 \\
\hline \multirow[t]{2}{*}{ Otidia } & $\begin{array}{l}\text { Pelargonium } \\
\quad \text { klinghardtense } \\
\quad(8)\end{array}$ & $\begin{array}{l}\left(2830^{\prime} \mathrm{S}, 1630^{\prime} \mathrm{E} \text { to } 27\right. \\
\left.35^{\prime} \mathrm{S}, 1640^{\prime} \mathrm{E}\right), \text { Gariep } \\
\text { Centre-succulent karoo, } \\
\text { granite, schist or } \\
\text { dolomite hills, } 200- \\
1,000 \mathrm{~m}\end{array}$ & $4-20$ & 25-75, also fog & Winter & $\begin{array}{l}\text { Stem } \\
\text { succulent }\end{array}$ & 6.4 \\
\hline & $\begin{array}{l}\text { Pelargonium } \\
\text { crithmifolium } \\
\text { (2) }\end{array}$ & $\begin{array}{l}\left(3150^{\prime} \mathrm{S}, 1838^{\prime} \mathrm{E}\right) \text {, Fynbos, } \\
\text { decomposed granite, well } \\
\text { drained } 100 \mathrm{~m}\end{array}$ & $6-20$ & 125 & Winter & $\begin{array}{l}\text { Stem } \\
\text { succulent }\end{array}$ & 20.1 \\
\hline
\end{tabular}

a Number of plants used for gas exchange measurements in parentheses

b Seeds sourced from collections growing at University of Connecticut, habitat description based on naturally occurring populations

c Seed sourced commercially, habitat description based on naturally occurring populations

replication, plants were moved monthly between the two compartments. Bench positions were maintained through the experiment. Moving the plants limited glasshouse aspect/light effects so the two growth temperature treatments had the same air, light, and soil treatments. Only temperature differed. 
Each plant was watered by an individual dripper on a stake in the pot at soil level. Water regimes were controlled by a Water-Pro vapour pressure deficit (VPD) control system (MicroGrow Greenhouse Systems, Temecula, Calif.). Watering events were triggered when pre-set VPD targets were reached. The low water VPD target was set $33 \%$ higher than the high water target; high water plants received $\sim 150 \mathrm{ml}$ per watering whereas low water plants received $\sim 70 \mathrm{ml}$ per watering. Watering occurred roughly once per week for low water plants and every 2-3 days for high water plants, depending on VPD in the glasshouse. If low and high water plants had been supplied with water at the same level, regardless of growth temperature, plants in the cooler house would effectively have had higher water availability than those in the warmer house. Instead, the VPD controlled system calculated VPD and delivered water at set VPD targets for each treatment and compartment of the house. Watering events for a given water treatment occurred at an equivalent target, not the same time, in the two houses. The higher water level was set to provide ample water without water-logging; the lower level was set at the minimum supported by the system and did not cause obvious wilting or leaf drop. Average relative humidity was significantly higher in the cool than hot temperature compartments ( $t$-test, $d f 193, P \leq 0.0001$, $58 \pm 13 \%$ and $40 \pm 12 \%$, respectively). Average VPD was 0.87 and $2.28 \mathrm{KPa}$ in the cool and hot houses, respectively.

Plants were fertilized biweekly with the commercially available water soluble fertilizer MiracleGro (N:P:K, $15: 13.1: 12.4)$. Initially, low water plants each received $50 \mathrm{ml}$ nutrient solution at $0.5 \mathrm{~g}$ fertilizer $1^{-1}$ water; high water plants each received $100 \mathrm{ml}$ of $0.25 \mathrm{~g} \mathrm{l}^{-1}$ solution. In mid-August plants had grown substantially and the concentration of fertilizer was increased by $50 \%$ to support the larger plants. No salt problems were apparent at any time.

\section{Leaf morphology}

The youngest fully expanded leaf was removed from each of ten plants per species per treatment in September 2003. Leaves were scanned on a flatbed scanner, their area determined using ImageJ (Rasband 1997-2005), and then dried at $70^{\circ} \mathrm{C}$ to constant weight. Specific leaf area (SLA; area/mass) was determined for each leaf. These were not the same leaves, or, in some cases, the same individuals, used for gas exchange analyses.

Gas exchange measurements

Thermal response of photosynthesis was measured with a LiCor 6400 portable photosynthesis system (LiCor,
Lincoln, Neb.) between 24 July and 27 November 2003 on 71 plants. Experimental plants $(n=1-5$ per species per treatment) were placed in the cool glasshouse $\left(18^{\circ} \mathrm{C}\right)$ to acclimate for $\sim 1 \mathrm{~h}$ before the youngest fully expanded leaf was placed in the infra-red gas analyser (IRGA) chamber for $10 \mathrm{~min}$ at $8^{\circ} \mathrm{C}$. Light level was maintained at saturating levels, $1,200 \mu \mathrm{mol} \mathrm{m} \mathrm{s}^{-2}$. Flow was set at $250 \mu \mathrm{mol} \mathrm{s}^{-1}$, and $\mathrm{CO}_{2}$ at $400 \mu \mathrm{mol}$. Every effort was made to moderate $\mathrm{VPD}_{1}$, but as temperature increased, so did $\mathrm{VPD}_{1}$. Across all measurements average $\mathrm{VPD}_{1}( \pm \mathrm{SD})$ was $2.3 \pm 1.6 \mathrm{KPa}$; at temperatures above $40^{\circ} \mathrm{C}$, average $\mathrm{VPD}_{1}$ was $5.31 \pm 1.52 \mathrm{KPa}$. All measurements were taken between sunrise and 2 p.m. Measurements were taken at $4^{\circ} \mathrm{C}$ intervals between 8 and $48^{\circ} \mathrm{C}$ allowing a maximum wait period of 6 min for stability (total coefficient of variation $<0.5 \%$ ) to be reached. While some Pelargonium species show low-level or facultative CAM photosynthesis (Jones et al. 2003), the study species have not been shown to use CAM and all were fixing diurnally.

\section{Curve fitting}

The temperature response of photosynthesis was assessed by fitting curves to the photosynthetic data for each plant in SPlus using the following model:

$$
\begin{aligned}
\text { Photosynthesis }= & (B-C \times \text { Leaf Temp }) \exp (\log (D) \\
& \times \text { Leaf Temp })
\end{aligned}
$$

The shapes of the fitted curves and fit of the data to the curves were good and were deemed appropriate for the data (Battaglia et al. 1996). Individual $r^{2}$-values exceeded 0.88 for all curves (median $=0.991)$. The parameters $B, C$ and $D$ were then recorded for each plant. These parameters do not directly describe plant traits, rather they were used to determine the biologically relevant parameters as described below. The temperature at which photosynthesis reached its maximum rate $\left(A_{\max }\right)$ was determined by setting the derivative of Eq. (1) equal to zero;

$T_{\text {opt }}=B / C-\log (D)$

At $T_{\text {opt }}$, the maximum rate of photosynthesis $\left(A_{\max }\right)$ is

$A_{\max }=C / \log (D) \times \exp [B / C \times \log (D)-1]$

$T_{\text {opt }}$ and $A_{\max }$ were calculated for each plant. Photosynthetic rates at 18 and $28^{\circ} \mathrm{C}$ were determined using Eq. (1).

The values of leaf temperature marking the endpoints of the range over which photosynthesis reaches $90 \%$ of its maximum value were numerically determined from the fitted curve for each plant. The difference between these values ( $\left.90 \% T_{\text {range }}\right)$ was calculated as an indication of the breadth of the temperature range over which the highest rates of photosynthesis are maintained. 
The shapes of the transpiration and conductance responses to change in leaf temperature varied so we could not fit a single parametric curve to all plants. A smoothing spline with $8^{\circ}$ of freedom was therefore fitted to the data from each plant, and used to interpolate values of transpiration, conductance and water use efficiency (WUE) at $18^{\circ} \mathrm{C}, T_{\text {opt }}, 28^{\circ} \mathrm{C}$ and at $A_{\text {max }}$.

\section{Analysis}

In the analyses we wished to focus on the effects of leaf shape, growth water and growth temperature treatments while analytically allowing or incorporating the differences between PICs or plants within PICs. Because our focus was on shape contrasts and not the particular species, or pairs, we treated species and PICs as random effects in all analyses. Plants were grown in two glasshouse compartments, one for each growth temperature; plants were blocked by PIC in matching positions in the two greenhouse compartments. Although the temperature treatments were not replicated in separate glasshouses, it was assumed for analyses that the individual plants were true replicates.

To assess whether leaf shape, growth water treatment and growth temperature treatment affected SLA, photosynthetic and water use traits, linear models were fitted to the key variables for each plant using GenStat (version 6; Numerical Algorithms Group, Oxford). Leaf shape, water treatment and temperature treatment were included as fixed effects, and PIC and replicate-nested-within-PIC as random effects. The full model was fitted first and residuals checked. One Pelargonium reniforme plant showed little temperature response and was excluded from analysis of $T_{\text {opt }}, 90 \% T_{\text {range }}$ and $\mathrm{WUE}_{\text {growth }}$, where its inclusion exerted high leverage and affected the fit of the model. One Pelargonium crithmifolium plant, a more-dissected species, had very high photosynthetic rates and was excluded for the sake of conservatism from $A_{\max }$ analysis. In two cases, transpiration values suggested thermocouple problems and WUE at growth temperature could not be calculated; these were missing values in that analysis. Full models were reduced by dropping non-significant terms starting with highest-order terms. Non-significant main effects were not dropped if they were significant in interaction terms.

We examined pairwise simple correlations among rainfall, latitude, gas exchange traits and an average dissection index [perimeter/square root(area), cf. McLellan and Endler 1998] for each species. For species whose seed was produced in cultivation, average rainfall and latitude from their native ranges were used. Dissection index was averaged across treatments for a given species using leaves ( $n \sim 20$ per species) from the larger glasshouse experiment. Pairwise correlations were judged significant if $r>0.38$, where $P<0.001$. Initial assessments included temperature variables as well, but there was little variance among sites in minimum, maximum and mean July temperatures (peak growing season for these winter growers), so these were not included in the final analysis.

\section{Results}

\section{Temperature shifts}

When considered across the range of measurement temperatures, the photosynthetic temperature response showed the expected pattern, increasing from low temperatures, flattening, and decreasing once leaf temperature exceeded $\sim 33^{\circ} \mathrm{C}$. As predicted, plants grown at $28 / 18^{\circ} \mathrm{C}$ reached their maximum rate of photosynthesis at higher temperatures, approximately $2^{\circ} \mathrm{C}$ higher than plants grown at 18 / $8^{\circ} \mathrm{C}$ (Fig. 1a, Table 2). The $T_{\text {opt }}$ were in the range of $33-$ $36^{\circ} \mathrm{C}$; however, these were higher than growth temperatures for both temperature treatments. These patterns held
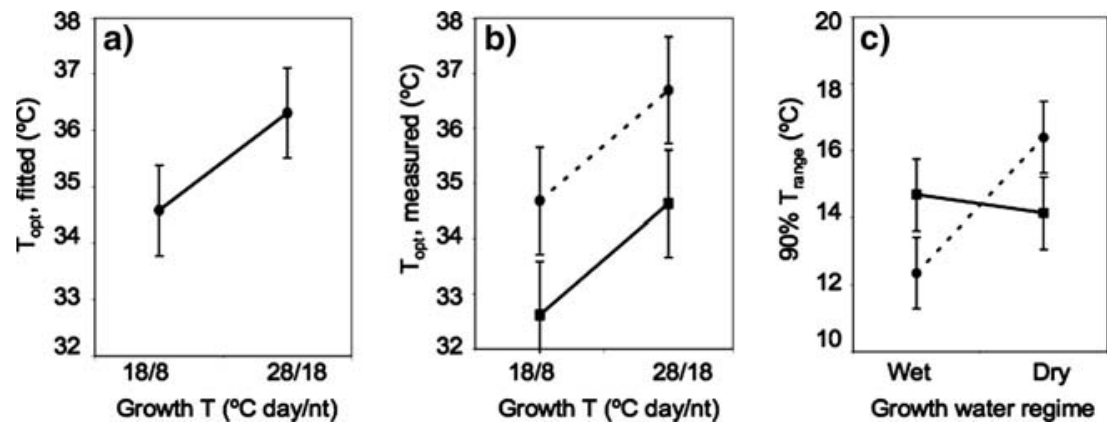

Fig. 1a-c Effects of growth treatments and leaf shape on leaf thermal traits. Dashed lines represent more-dissected species and solid lines the less-dissected species. a Optimal temperature $\left(T_{\text {opt }}\right)$ for photosynthesis fitted from curve, $\mathbf{b} T_{\mathrm{opt}}$ from nearest direct measure-

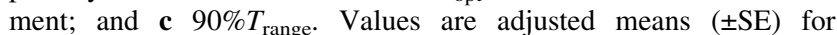
significant treatment effects only (see Table 2). $n t$ Night 
Table 2 Results of linear mixed models. Wald statistic and $P$-value presented for all terms included in models; $d f$ for all effects is 1 . Empty cells represent terms dropped from models. $n$ Number of units in the analysis, WUE water use efficiency, SLA specific leaf area

\begin{tabular}{|c|c|c|c|c|c|c|c|c|c|c|c|c|c|}
\hline & \multirow[t]{2}{*}{$n$} & \multicolumn{2}{|c|}{ Leaf shape } & \multicolumn{2}{|c|}{ Water treatment } & \multicolumn{2}{|c|}{$\begin{array}{l}\text { Temperature } \\
\text { treatment }\end{array}$} & \multicolumn{2}{|c|}{$\begin{array}{l}\text { Leaf shape } \times \\
\text { Water }\end{array}$} & \multicolumn{2}{|c|}{$\begin{array}{l}\text { Leaf shape } \times \\
\text { Temperature }\end{array}$} & \multicolumn{2}{|c|}{$\begin{array}{l}\text { Leaf shape } \times \text { Water } \times \\
\text { Temperature }\end{array}$} \\
\hline & & Wald & $P$ & Wald & $P$ & Wald & $P$ & Wald & $P$ & Wald & $P$ & Wald & $P$ \\
\hline \multicolumn{14}{|l|}{ Temperature $^{\mathrm{a}}(T)$} \\
\hline$T_{\mathrm{opt}}$, fitted & 70 & & & & & 4.29 & 0.038 & & & & & & \\
\hline$T_{\mathrm{opt}}$, measured & 71 & 3.03 & 0.034 & & & 4.51 & 0.035 & & & & & & \\
\hline$T_{\text {range }}$ & 70 & 0.52 & 0.473 & 2.39 & 0.122 & & & 9.12 & 0.003 & & & & \\
\hline \multicolumn{14}{|l|}{ Photosynthesis $^{\mathrm{a}}(A)$} \\
\hline$A_{18}$ & 71 & 17.65 & 0.001 & 4.44 & 0.035 & 11.32 & 0.001 & & & & & & \\
\hline$A_{28}$ & 71 & 30.24 & 0.001 & & & 7.82 & 0.005 & & & & & & \\
\hline$A_{\text {growth }}$ & 71 & 17.71 & 0.001 & 4.13 & 0.042 & & & & & & & & \\
\hline$A_{\max }$, fitted & 70 & 36.97 & 0.001 & 6.37 & 0.066 & 7.10 & 0.008 & & & & & 5.42 & 0.020 \\
\hline$A_{\max }$, measured & 70 & 38.29 & 0.005 & 3.85 & 0.050 & 7.90 & 0.005 & & & & & 6.30 & 0.012 \\
\hline \multicolumn{14}{|l|}{ Water use $^{\mathrm{a}}$} \\
\hline Conductance $_{18}$ & 71 & 6.45 & 0.011 & 9.49 & 0.002 & & & 3.90 & 0.048 & & & & \\
\hline Conductance $_{28}$ & 71 & 9.80 & 0.002 & 6.71 & 0.010 & & & & & & & & \\
\hline Conductance $_{\text {growth }}$ & 71 & 9.20 & 0.002 & 8.77 & 0.002 & & & 5.06 & 0.024 & & & & \\
\hline Conductance $_{\mathrm{MP}}$ & 71 & 2.09 & 0.149 & 2.01 & 0.157 & & & 3.87 & 0.050 & & & & \\
\hline Transpiration $_{18}$ & 71 & 6.15 & 0.013 & 4.89 & 0.027 & & & & & & & & \\
\hline Transpiration $_{28}$ & 71 & 12.39 & 0.001 & & & & & & & & & & \\
\hline Transpiration $_{\text {growth }}$ & 71 & 7.34 & 0.007 & & & 41.27 & 0.001 & & & & & & \\
\hline Transpiration $_{\mathrm{MP}}$ & 71 & 9.36 & 0.002 & & & & & & & & & & \\
\hline $\mathrm{WUE}_{18}$ & 71 & & & & & & & & & & & & \\
\hline $\mathrm{WUE}_{28}$ & 71 & & & & & 5.03 & 0.025 & & & & & & \\
\hline WUE $_{\text {growth }}$ & 69 & & & & & 36.07 & 0.001 & & & & & & \\
\hline WUE $_{\mathrm{MP}}$ & 70 & & & & & 8.42 & 0.004 & & & & & & \\
\hline SLA & 257 & 8.18 & 0.004 & 12.43 & 0.001 & 14.27 & 0.001 & & & 6.23 & 0.013 & & \\
\hline
\end{tabular}

${ }^{a}$ opt Optimum, $1818^{\circ} \mathrm{C}, 2828^{\circ} \mathrm{C}$, growth growth temperature, max maximum, $M P$ temperature at which $A_{\max }$ was measured

for both fitted values from the thermal response curves and measured temperatures for maximal rates of photosynthesis. When measured as opposed to fitted values were considered, species with more-dissected leaves had optimal temperatures $2^{\circ} \mathrm{C}$ higher than those with less-dissected leaves (Fig. 1b, Table 2).

The breadth of the temperature range at which plants are able to maintain $\geq 90 \%$ of maximum photosynthetic rate (90\% $T_{\text {range }}$ ) may be indicative of the breadth of temperatures over which the plant can maintain optimal rates of photosynthesis. We found that the $90 \% T_{\text {range }}$ was unaffected by growth temperature, but there were leaf shape effects that were dependent on water conditions. Compared to less-dissected species, those with more-dissected leaves had larger $90 \% T_{\text {range }}$ when grown at high water, and narrower ranges when grown at low water (Fig. 1c; Table 2). Species with less-dissected leaves showed no effect of growth water treatment on $90 \% T_{\text {range }}$. This same pattern emerged when ranges on either side of optimal were considered independently (results not shown).
Photosynthetic rates

In general, plants grown under wetter conditions, at cool temperatures and with more-dissected leaves had higher rates of photosynthesis than their dry, hot or less-dissected counterparts (Table 2). This pattern held for measurement temperatures of 18 or $28^{\circ} \mathrm{C}$, regardless of growth temperature (Fig. 2a, b). When photosynthetic rate was compared at growth temperature, there was no main effect of growth temperature because plants grown at $28^{\circ} \mathrm{C}$ achieved similar rates of photosynthesis at $28^{\circ} \mathrm{C}$ as $18^{\circ} \mathrm{C}$-grown plants at $18^{\circ} \mathrm{C}$ (Table 2, cf. Fig. 2a, b). However, even when compared at growth temperatures, plants with more-dissected leaves and those grown under wet conditions had significantly higher rates of photosynthesis than less-dissected or dry-grown plants (Fig. 2c).

For maximum photosynthetic rate there was a significant three-way (shape by temperature by water treatment) interaction (Table 2, Fig. 2d). More-dissected leafed plants had higher maximal rates, and plants grown at cool 

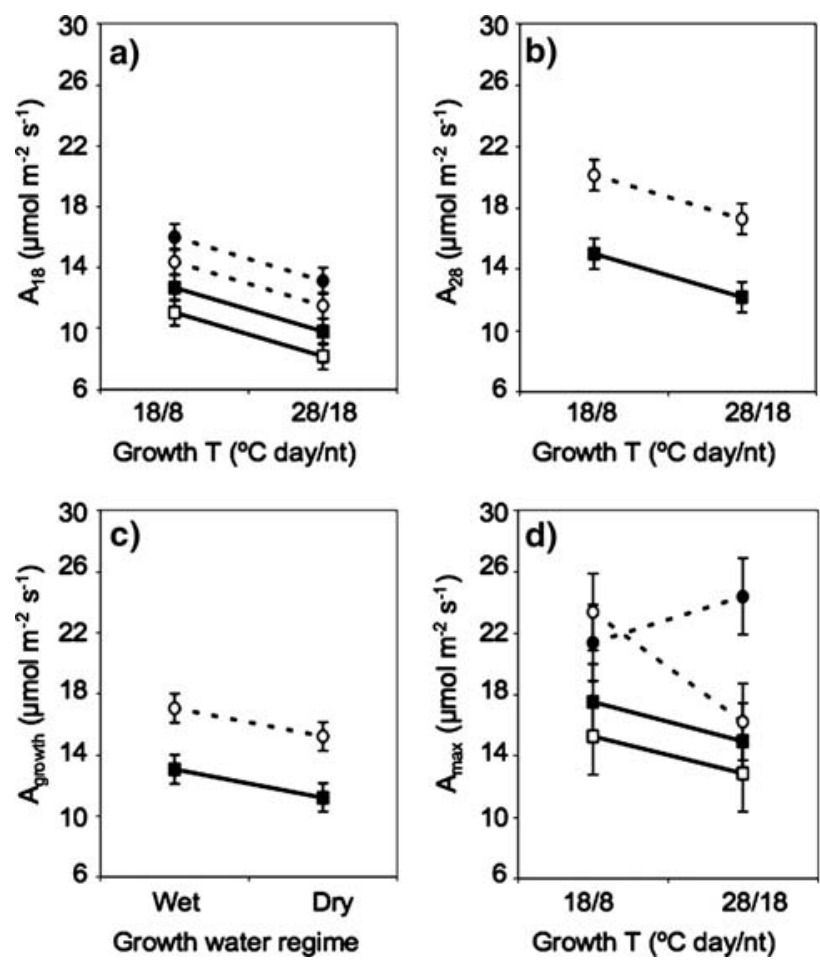

Fig. 2 Effects of growth treatments and leaf shape on photosynthetic rate $\left(\mu \mathrm{mol} \mathrm{m} \mathrm{m}^{-2} \mathrm{~s}^{-1}\right)$ at $\mathbf{a} 18^{\circ} \mathrm{C}, \mathbf{b}$ at $28^{\circ} \mathrm{C}, \mathbf{c}$ compared at growth temperature, and $\mathbf{d}$ compared at modelled maximum rate of photosynthesis $\left(A_{\max }\right)$. a-c Dashed lines represent more-dissected species and solid lines the less-dissected species. a, $\mathbf{d}$ Dashed lines are as above, and open and closed symbols represent low and high water, respectively. Values are adjusted means $( \pm \mathrm{SE})$ for significant treatment effects only (see Table 2). For an explanation of subscripts, see Table 2

temperatures had higher maximal rates in all cases except for more-dissected leafed plants grown under wet conditions, where hot-grown plants had significantly higher maximal rates. Plants grown at low water had lower rates of photosynthesis than plants grown at high water, although dissected-leafed species grown at cool temperatures did not significantly differ in rate between water treatments. These results for maximum photosynthetic rates were identical whether measured or fitted values were analysed.

\section{Water use}

Stomatal conductance to water was affected by growth water level and leaf shape in a similar manner to photosynthetic rate: plants with more-dissected leaves and those grown at high water had higher conductance than their counterparts (Table 2). At $18^{\circ} \mathrm{C}$ and at growth temperature, a significant water by shape interaction resulted; the water effect on conductance was only significant among the more-dissected leafed plants (Fig. 3a, c). At $28^{\circ} \mathrm{C}$, moredissected leafed species had higher conductance than those with less-dissected leaves, and wet-grown plants had higher conductance than dry-grown ones; there were no significant interactions (Fig. 3b). In contrast, when compared at the temperature at which maximum photosynthetic rate was reached, conductance was lower and plants with more-dissected leaves had relatively higher conductance than less-dissected leafed species, but only under dry conditions (Fig. 3d). There were no significant direct effects or interaction effects of growth temperature on conductance.

Transpiration, like conductance, was higher in moredissected leaf species than less-dissected leaves (Table 2, Fig. 3e). Wet-grown plants had significantly higher transpiration rates than dry-grown plants but only when compared at $18^{\circ} \mathrm{C}$ (Table 2). Transpiration also increased with leaf temperature such that, when compared at growth temperature, hot-grown plants had higher transpiration rates than cool-grown plants (Table 2). Given that plants grown at $18 / 28^{\circ} \mathrm{C}$ day/night had higher rates of photosynthesis, and lower water use, it follows that they also had higher instantaneous WUE (Table 2, Fig. 3f).

\section{Specific leaf area}

SLA was significantly higher at low water than high (Table 2, Fig. 4a). Leaf shape and growth temperature had interactive effects on SLA, with more-dissected leaves having significantly lower SLA than less-dissected leaves when grown at cool temperatures. This difference was not apparent at high temperatures, nor was there an effect of temperature on SLA in the less-dissected leaves (Fig. 4b).

\section{Other explanatory variables}

Analysis of correlations among gas exchange traits revealed expected patterns (Fig. 5). As was the case using the two-state descriptor of leaf shape (less- versus moredissected), the correlation analysis also supported the result that species with higher degrees of dissection had higher photosynthetic rates and transpiration rates at maximum photosynthetic rate $(r=0.52$ and 0.38 , respectively, $n=71$, both $P<0.001)$. Rainfall was significantly lower at more northern latitudes $(r=0.66, n=70, P<0.001)$ and plants from further north had significantly higher maximal photosynthetic rates and conductance at maximum photosynthesis $(r=-0.40$ and -0.50 , respectively, $n=71, P<0.001)$. However, neither $T_{\text {opt }}$ nor leaf dissection index was correlated with rainfall or latitude so the relationship between these traits and carbon gain are likely to hold within climatic regions as well as among them. 
Fig. 3a-d Effects of growth treatments and leaf shape on water use traits. a Stomatal conductance $\left(\mathrm{mol} \mathrm{m}^{-2} \mathrm{~s}^{-1}\right)$ at $18^{\circ} \mathrm{C}, \mathbf{b}$ at $28^{\circ} \mathrm{C}, \mathbf{c}$ at growth temperatures, and $\mathbf{d}$ when compared at $A_{\text {max }}$. rate and $\mathbf{f}$ water use efficiency (WUE) are compared at growth temperature. a-e Dashed lines represent more-dissected species and solid lines the lessdissected species. Values are adjusted means $( \pm$ SE) for significant treatment effects only (see Table 2). For an explanation of subscripts, see Table 2; for abbreviations, see Figs. 1 and 2 e Transpiration $\left(\mathrm{mol} \mathrm{m} \mathrm{m}^{-2} \mathrm{~s}^{-1}\right)$
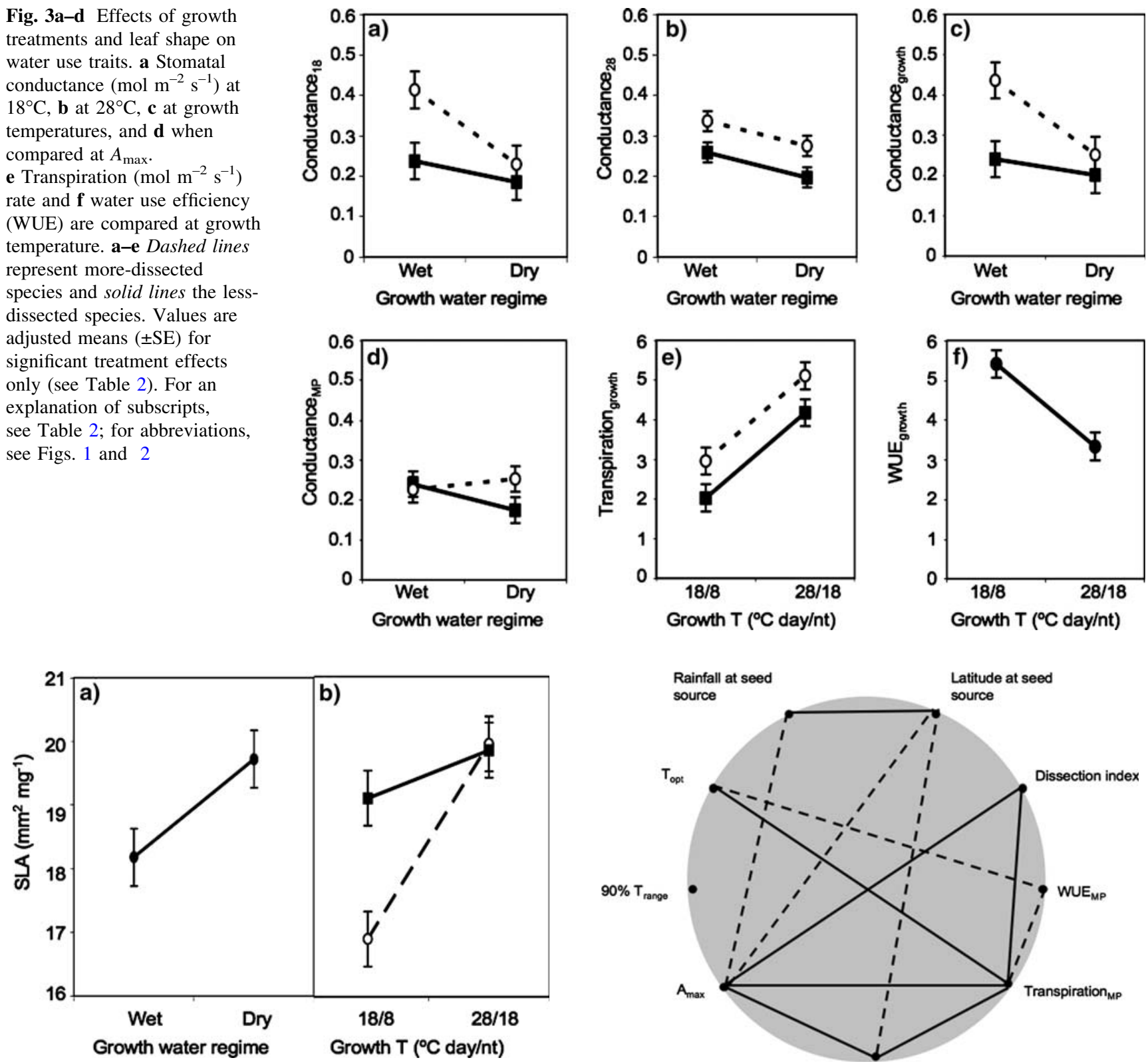

Fig. 4 Effect of $\mathbf{a}$ growth water regime and $\mathbf{b}$ growth temperature on specific leaf area $\left(S L A ; \mathrm{mm}^{2} \mathrm{mg}^{-1}\right)$. b Dashed lines represent moredissected species and solid lines the less-dissected species. Values are adjusted means $( \pm \mathrm{SE})$ for significant treatment effects only (see Table 2)

\section{Discussion}

As predicted, Pelargonium species showed plasticity in photosynthetic capacity in response to differences in both water and temperature regimes. Plants grown at $28 / 18^{\circ} \mathrm{C}$ achieved their photosynthetic optima at higher temperatures, but attained lower photosynthetic rates than plants grown at $18 / 8^{\circ} \mathrm{C}$. Wet-grown plants also had higher photosynthetic rates, but water level had no effect on the optimum temperature for photosynthesis. Such a tradeoff

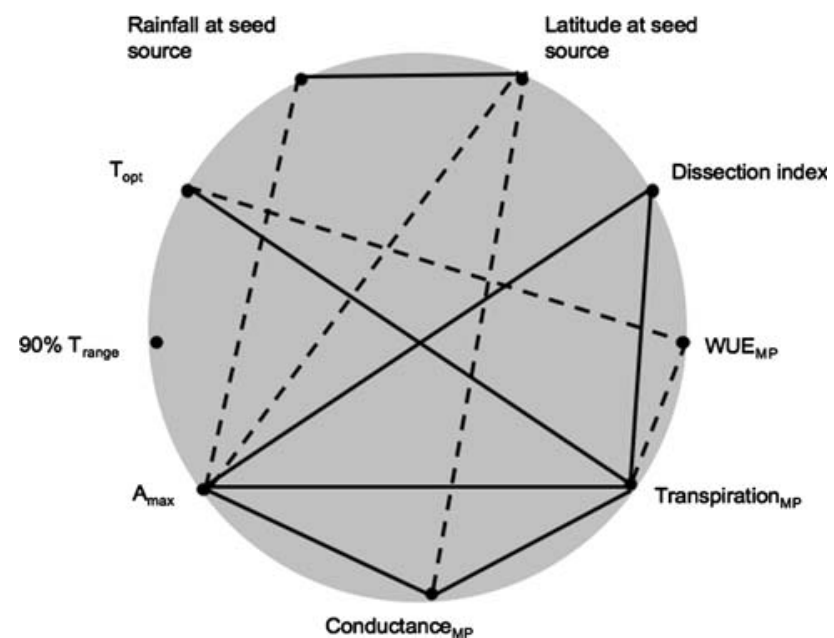

Fig. 5 Significant correlations $(r>0.38, \quad P<0.001, \quad d f=71)$, between rainfall and latitude at the source seed site, gas exchange traits and dissection index as a species average across treatments. Positive correlations are presented as solid lines, negative correlations as dashed lines. For an explanation of subscripts, see Table 2; for abbreviations, see Figs. 1, 2 and 4

between increased thermal optima and decreased photosynthetic capacity is well known (Berry and Björkman 1980).

In some species, growth at high temperature results in a sharply reduced $90 \% T_{\text {range }}$ (Turnbull et al. 2002). In our study, thermal optima were quite high across treatments, and the temperature ranges at which $90 \%$ or more of photosynthetic maxima were maintained were broad. The 
breadth of this range may be indicative of species or ecotypes from more variable environments (Battaglia et al. 1996; Cunningham and Read 2002), but among Pelargonium species there seems to be little differentiation. While rainfall varies both between years and among the habitats of these species, temperature regimes during the growing seasons are very similar across the range. Rainfall variation may explain the breadth of the $90 \% T_{\text {range }}$ and the similarity of temperature regimes may explain the concordance of the $90 \% T_{\text {range }}$ of the Pelargonium species studied here.

Although previous studies have demonstrated growth temperature effects on stomatal function (Ogle and Reynolds 2002, and references therein), our results showed no evidence of a growth temperature effect on conductance or transpiration at 18 or $28^{\circ} \mathrm{C}$ or at maximum photosynthetic rate. Even though we did not find direct effects of growth temperature on conductance, transpiration is inevitably higher at higher temperatures, and when coupled with the decline in photosynthetic capacity in plants grown at high temperatures results in a significant reduction in WUE at the higher growth temperature.

Stomatal closure is generally the first response to drought and is the dominant limitation to photosynthesis at mild and moderate drought (Flexas and Medrano 2002). We note that stomatal conductance in the plants in the present experiment was seldom lower than $0.100 \mathrm{~mol} \mathrm{~m}^{-}$ ${ }^{2} \mathrm{~s}^{-1}$, suggesting that while we elicited growth water effects, we did not dramatically water stress these aridadapted species. Neither did we find clear indications of greater thermotolerance in the low water plants (Havaux 1992; Valladares et al. 1997; Ladjal et al. 2000). Some species of Pelargonium are capable of low level CAM cycling under extreme water stress (Jones et al. 2003). As such, we are curious to assess how Pelargoniums in general behave under more severe water stress, and whether those capable of CAM cycling differ in thermotolerance and stomatal responses.

Our most intriguing results were the significant effects of leaf shape: species with more-dissected leaves had higher thermal optima and greater rates of carbon gain and water loss. A more dissected leaf shape will result in thinner boundary layer and more effective convective heat exchange with the environment. So under natural conditions, more-dissected leaves will track ambient conditions more closely and potentially show smaller leaf to air temperature differences than a less divided leaf (Nobel 1983; and see references in Schuepp 1993). We did not measure leaf temperatures directly, and so cannot say whether the more-dissected species operated on average at lower temperatures than the less-dissected species. Recent work demonstrates that effects of leaf shape on canopy temperature may be less than effects of overall canopy architecture and density (Leuzinger and Körner 2007), so it is hard to predict what the actual photosynthetic operating temperatures of these Pelargonium species would be. However, if the more-dissected species did operate at lower leaf temperatures on average as predicted by boundary layer theory, it is all the more striking that they have higher thermal optima at a given growth temperature than their less-dissected counterparts.

Our results are one of only a few demonstrations of physiological divergence between closely related taxa differing in leaf shape. Previous studies have all focused on variation within a species, and have not demonstrated consistent patterns. Gurevitch $(1988,1992)$ reported that ecotypes of Achillea millefolium that differed genetically in leaf dissection also differed in assimilation rates; the lessdissected form had higher rates. In contrast, a dissected leaf form of Ranunculus repens was found to have higher rates of both photosynthesis and conductance than the typical broad-leaf form (Lynn and Waldren 2002). And finally, Stiller et al. (2004 and references therein) found that okraleaf cultivars (a dissected leaf) of cotton (Gossypium hirsutum) had higher photosynthetic rates and also higher WUE.

The correlations we demonstrate here, between leaf dissection and high rates of carbon gain and water loss across species, could reflect direct causal links between shape and carbon gain, or instead represent the outcome of correlated evolutionary responses to selective conditions. As such, one argument is that the higher rates of photosynthesis we observed are a result of boundary layer differences between the leaf types. We reject this explanation as a primary cause of the difference in photosynthetic rates because all of our measurements were made in a closed IRGA chamber with a fast chamber fan and moderately high rates of air-flow through the IRGA. These conditions would have effectively removed the boundary around all leaves during the gas exchange measurements, regardless of shape.

We prefer the alternative argument, that selection favours a more dissected leaf shape in hot dry conditions, and that these same conditions are those that favour the evolution of high photosynthetic rates, high leaf nitrogen content and opportunistic use of water when available (Wright et al. 2001, 2004; Heschel and Riginos 2005; Donovan et al. 2007). Analysis of SLA supports this interpretation; the more-dissected leaves also had lower SLA than less-dissected leaves (when grown at $18 / 8^{\circ} \mathrm{C}$ ). The lower SLA would most likely result from veins making up a relatively greater proportion of the mass of morethan less-dissected leaves, and may lead to equivalent photosynthetic rates on a mass basis. Further investigations may more effectively reveal functional correlates of leaf shape, where other factors can be intentionally held constant. 
Global climate change, and in particular increased temperatures, especially in a context of water stress, will lead to marked decreases in productivity (Sharkey 2005). South African species like the Pelargoniums studied here may be particularly susceptible to shifts in environmental parameters because the group exhibits high levels of endemism and often very narrow geographic ranges (Midgley et al. 2002; Midgley et al. 2003; Hannah et al. 2005, Thuiller et al 2006). Our work suggests that in predicting responses to increases in temperature and drought, links between leaf shape, morphology and thermal tolerance, in response to both long- and short-term changes in conditions, should be considered (Sharkey 2005). To understand those responses, one would have to understand heating and cooling dynamics of these leaves and how those dynamics scale to the canopy level, in partnership with dynamic measurements of photosynthetic and transpiration responses to temperature changes.

Given that natural growth temperatures of these Pelargonium species are generally less than $30^{\circ} \mathrm{C}$ (Table 1), it seems likely that direct effects of leaf temperature on photosynthetic machinery will be small (Martin et al. 1999; Ward et al. 2001). At least from the data on this collection of eight species, indications are that leaf temperature effects may be more important as determinants of water loss, than as determinants of photosynthetic rates, therefore indirectly affecting productivity, rather than directly inhibiting photosynthetic processes themselves. Stomatal responses to temperature are likely to be critical mediators of the effect of temperature on realized carbon gain. In the Pelargoniums, the combination of dissected leaves, higher photosynthetic rates, and relatively low WUE may have evolved as a strategy to optimise water delivery and carbon gain during short periods of high soil moisture. The correlation between higher temperature and leaf dissection may reflect selection pressure to protect photosynthetic machinery against excessive leaf temperatures when stomata close in response to water stress.

Acknowledgements We thank Christine Donnelly for help with data analysis, Susanne von Caemmerer for insightful discussion of the results, and Rachel Saunders (http://www.silverhillseeds.co.za) for seed collection. Two anonymous reviewers provided constructive comments on a previous version of the manuscript. This work was supported by an Australian Research Council grant to A. B. N., C. S. J. and C. D. S

\section{References}

Atkin OK, Loveys BR, Atkinson LJ, Pons TL (2006) Phenotypic plasticity and growth temperature: understanding interspecific variability. J Exp Bot 57:267-281

Bakker FT, Culham A, Hettiarachi P, Touloumenidou T, Gibby M (2004) Phylogeny of Pelargonium (Geraniaceae) based on DNA sequences from three genomes. Taxon 53:17-28
Battaglia M, Beadle C, Loughhead S (1996) Photosynthetic temperature responses of Eucalyptus globulus and Eucalyptus nitens. Tree Physiol 16:81-89

Berry J, Björkman O (1980) Photosynthetic response and adaptation to temperature in higher-plants. Annu Rev Plant Physiol Plant Mol Biol 31:491-543

Burt A (1989) Comparative methods using phylogenetically independent contrasts. Oxf Surv Evol Biol 6:33-53

Cunningham SC, Read J (2002) Comparison of temperate and tropical rainforest tree species: photosynthetic responses to growth temperature. Oecologia 133:112-119

Donovan LA, Dudley S, Rosenthan D, Ludwig F (2007) Phenotypic selection on leaf water use efficiency and related ecophysiological traits for natural populations of desert sunflowers. Oecologia 152:13-25

Downton WJS, Berry JA, Seeman JR (1984) Tolerance of photosynthesis to high temperature in desert plants. Plant Physiol 74:786790

Dwyer SA, Ghannoum O, Nicotra AB, Von Caemmerer S (2007) High temperature acclimation of $\mathrm{C}_{4}$ photosynthesis is linked to changes in photosynthetic biochemistry. Plant Cell Environ 30:53-66

Flexas J, Medrano H (2002) Drought-inhibition of photosynthesis in $\mathrm{C}_{3}$ plants: stomatal and non-stomatal limitations revisited. Ann Bot 89:183-189

Froux F, Ducrey M, Epron D, Dreyer E (2004) Seasonal variations and acclimation potential of the thermostability of photochemistry in four Mediterranean conifers. Ann For Sci 61:235-241

Gurevitch J (1988) Variation in leaf dissection and leaf energy budgets among populations of Achillea from an altitudinal gradient. Am J Bot 75:1298-1306

Gurevitch J (1992) Differences in photosynthetic rate in populations of Achillea lanulosa from two altitudes. Funct Ecol 6:568-574

Haldimann P, Feller U (2005) Growth at moderately elevated temperature alters the physiological response of the photosynthetic apparatus to heat stress in pea (Pisum sativum L.) leaves. Plant Cell Environ 28:302-317

Hannah L, Midgley G, Hughes G, Bomhard B (2005) The view from the cape. Extinction risk, protected areas, and climate change. Bioscience 55:231-242

Havaux M (1992) Stress tolerance of photosystem II in vivo. Plant Physiol 100:424-432

Hegazy A, El Amry M (1998) Leaf temperature of desert sand dune plants: perspectives on the adaptability of leaf morphology. Afr J Ecol 36:34-43

Heschel MS, Riginos C (2005) Mechanisms of selection for drought stress tolerance and avoidance in Impatiens capensis (Balsaminacea). Am J Bot 92:37-44

Hikosaka K, Murakami A, Hirose T (1999) Balancing carboxylation and regeneration of ribulose-1,5-bisphosphate in leaf photosynthesis: temperature acclimation of an evergreen tree, Quercus myrsinaefolia. Plant Cell Environ 22:841-849

Hikosaka K, Ishikawa K, Borjigidai A, Muller O, Onoda Y (2006) Temperature acclimation of photosynthesis: mechanisms involved in the changes in temperature dependence of photosynthetic rate. J Exp Bot 57:291-302

Jones CS, Cardon ZG, Czaja AD (2003) A phylogenetic view of lowlevel CAM in Pelargonium (Geraniaceae). Am J Bot 90:135142

Knight CA, Ackerly DD (2002) An ecological and evolutionary analysis of photosynthetic thermotolerance using the temperature-dependent increase in fluorescence. Oecologia 130:505-514

Knight CA, Ackerly DD (2003) Evolution and plasticity of photosynthetic thermal tolerance, specific leaf area and leaf size: congeneric species from desert and coastal environments. New Phytol 160:337-347 
Ladjal M, Epron D, Ducrey M (2000) Effects of drought preconditioning on thermotolerance of photosystem II and susceptibility of photosynthesis to heat stress in cedar seedlings. Tree Physiol 20:1235-1241

Lange OL, Geiger IL, Schulze ED (1977) Ecophysiological investigations on lichens of the Negev Desert. V. A model to simulate net photosynthesis and respiration of Mammalina maciformis. Oecologia 28:247-259

Larcher W (1995) Physiological plant ecology, 3rd edn. Springer, Berlin

Leuzinger S, Körner C (2007) Tree species diversity affects canopy leaf temperatures in a mature temperate forest. Agric For Meteorol (in press). doi:10.1016/j.agrformet.2007.05.007

Lynn DE, Waldren S (2002) Physiological variation in populations of Ranunculus repens $\mathrm{L}$. (creeping buttercup) from the temporary limestone lakes (turloughs) in the west of Ireland. Ann Bot 89:707-714

Mahan JR, Upchurch DR (1988) Maintenance of constant leaf temperature by plants. 1. Hypothesis limited homeothermy. Environ Exp Bot 28:351-357

Martin TA, Hinckley TM, Meinzer FC, Sprugel DG (1999) Boundary layer conductance, leaf temperature and transpiration of Abies amabilis branches. Tree Physiol 19:435-443

McDonald PG, Fonseca CR, Overton JM, Westoby M (2003) Leafsize divergence along rainfall and soil-nutrient gradients: is the method of size reduction common among clades? Funct Ecol 17:50-57

McLellan T, Endler JA (1998) The relative success of methods for measuring and describing the shape of complex objects. Syst Biol 47:264-281

Medlyn BE, et al. (2002) Temperature response of parameters of a biochemically based model of photosynthesis. II. A review of experimental data. Plant Cell Environ 25:1167-1179

Midgley GF, Hannah L, Millar D, Rutherford MC, Powrie LW (2002) Assessing the vulnerability of species richness to anthropogenic climate change in a biodiversity hotspot. Glob Ecol Biogeogr 11:445-451

Midgley GF, Hannah L, Millar D, Thuiller W, Booth A (2003) Developing regional and species-level assessments of climate change impacts on biodiversity in the Cape Floristic Region. Biol Conserv 112:87-97

Nobel PS (1983) Biophysical plant physiology and ecology. Freeman, San Francisco, Calif.

Ogle K, Reynolds JF (2002) Desert dogma revisited: coupling of stomatal conductance and photosynthesis in the desert shrub, Larrea tridentata. Plant Cell Environ 25:909-921

Radin JW, Lu ZM, Percy RG, Zeiger E (1994) Genetic-variability for stomatal conductance in Pima cotton and its relation to improvements of heat adaptation. Proc Natl Acad Sci USA 91:7217-7221

Rasband WS (1997-2005) ImageJ. US National Institutes of Health, Bethesda, Md.

Schuepp PH (1993) Tansley review no. 59: leaf boundary layers. New Phytol 125:477-507
Shabala SN (1996) Leaf temperature kinetics measure plant adaptation to extreme high temperatures. Aust J Plant Physiol 23:445452

Sharkey TD (2005) Effects of moderate heat stress on photosynthesis: importance of thylakoid reactions, rubisco deactivation, reactive oxygen species, and thermotolerance provided by isoprene. Plant Cell Environ 28:269-277

Smith WK (1978) Temperatures of desert plants: another perspective on the adaptability of leaf size. Science 201:614-616

Stiller WN, Reid PE, Constable GA (2004) Maturity and leaf shape as traits influencing cotton cultivar adaptation to dryland conditions. Agron J 96:656-664

Thuiller W, Midgley GF, Hughes GO, Bomhard B, Drew G, Rutherford MC, Woodward FI (2006) Endemic species and ecosystem sensitivity to climate change in Namibia. Glob Change Biol 12:759-776

Turnbull MH, Murthy R, Griffin KL (2002) The relative impacts of daytime and night-time warming on photosynthetic capacity in Populus deltoides. Plant Cell Environ 25:1729-1737

Upchurch DR, Mahan JR (1988) Maintenance of constant leaf temperature by Plants. 2. Experimental observations in cotton. Environ Exp Bot 28:359-366

Valladares F, Pearcy RW (1997) Interactions between water stress, sun-shade acclimation, heat tolerance and photoinhibition in the sclerophyll Heteromeles arbutifolia. Plant Cell Environ 20:2536

Valladares F, Allen MT, Pearcy RW (1997) Photosynthetic responses to dynamic light under field conditions in six tropical rainforest shrubs occurring along a light gradient. Oecologia 111:505-514

van der Walt JJA (1977) Pelargoniums of Southern Africa, vol 1. Juta, Cape Town

van der Walt JJA, Vorster PJ (1981) Pelargoniums of Southern Africa, vol 2. Juta, Cape Town

van der Walt JJA, Vorster PJ (1988) Pelargoniums of Southern Africa, vol 3. Annals of Kirstenbosch Botanic Gardens, 16 edn. National Botanic Gardens, Kirstenbosch

Ward SJE, Esler KJ, Bowie MR (2001) Seasonal photosynthetic temperature responses and changes in $\delta^{13} \mathrm{C}$ under varying temperature regimes in leaf-succulent and drought-deciduous shrubs from the Succulent Karoo. S Afr J Bot 67:235-243

Wright IJ, Reich PB, Westoby M (2001) Strategy shifts in leaf physiology, structure and nutrient content between species of high- and low-rainfall and high- and low-nutrient habitats. Funct Ecol 15:423-434

Wright IJ, et al. (2004) The worldwide leaf economics spectrum. Nature 428:821-827

Xiong FS, Ruhland CT, Day TA (1999) Photosynthetic temperature response of the Antarctic vascular plants Colobanthus quitensis and Deschampsia antarctica. Physiol Plant 106:276-286

Yamori W, Noguchi K, Terashima I (2005) Temperature acclimation of photosynthesis in spinach leaves: analyses of photosynthetic components and temperature dependencies of photosynthetic partial reactions. Plant Cell Environ 28:536-547 